Elephas planifrons. In that species the premolars do verti. cally displace the milk-molars, as is shown in the "Fauna Antiqua Sivalensis."

P. 389.-Dinotherium is not mentioned as occurring in India, and $D$. giganteum is said to be the only species. Two species were named by Falconer in India!

P. 395.-We read: "The earliest remains of Melide are from the upper miocene deposits of the Siwalik Hills in India, in which we meet with the living genus Mellizora (comprising the Honey-Badgers), and the allied but extinct Ursitaxus." Ursitaxus is not an extinct genus, but the generic synonym given by Hodgson for Mellivora indica! There is only one species of Meiida from the Siwaliks, Mellivora (Ursitaxus) sivalensis.

P. 396.-Ictitherium is mentioned as occurring only in Attica, no notice being taken of the Indian species described in our Records for February, 1877 .

P. 402.-Pseudalurus is only mentioned from Europe and America, the Siwalik species described in our Records for May, 1877 , being ignored.

Other instances of omission occur in the book, which might be noticed here, but sufficient have been quoted to show that as regards Indian vertebrate palæontology, even up to the beginning of 1878 , the work is not trustworthy. It is to be presumed that a writer would not willingly disfigure his own work, yet what can be said of a compiler who, in writing on Indian palæontology, omits to refer to the publications of the Geological Survey of that country.

Indian Museum, Calcutta, February 3

\section{The Mean Free Path of Molecules}

Mr. CroOKEs estimates that a bulb $5^{\frac{1}{4}}$ inches diameter, attenuated $\mathrm{r}, 000$, 000-fold, would contain a trillion of molecules.

Assuming in round numbers such a space to contain roo cubic inches, there would be I0,000 billions per cubic inch.

The molecules, considered as mathematical points, would have a mean distance a part of less than 000005 inches.

The cube of 200,000 gives 8,000 billions instead of 10,000 ; therefore a linear inch would contain more than 200,000 in any direction.

How then can the mean free path of actual molecules be considered as from 2 to 6 inches?

\section{The Zoological Station, or Aquarium, at Naples}

When, last week, you referred to the account in the Daily News of the above-named institution, ycu omitted what you probably did not know, which is, that, as you will see by the accompanying copy of a letter from Dr. Anton Dohrn to Dr. W. B. Carpenter, it was I who devised all the aquarium portions of the place, and that my ideas were carried out by the engineers, Messrs. Leete, Edwards, and Norman. But I had nothing to do with the laboratory part of the establishment.

We are now so accustomed to aquaria, as being useful adjuncts to biological studies, that it may surprise many persons to be informed that in the earliest published official notice of the Crystal Palace, Sydenham, a now very rare duodecimo of thirtyfive pages, dated September 22, 1852, it is stated on pages 22 and 23 that, owing to the difficulty, amounting to what seemed to be impos ibility, of exhibiting living marine animals inland, in seawater, they, the fish, crustacea, mollusca, zoophytes, \&c., would be shown dead, but, "on a plan not hitherto tried, that of making them appear to be swimming in very large glass vessels containing a sufficient quantity of some preservative fiuid having the appearance of water."

Something of this kind was attempted by Dr. Bowerbank, but it was not till the year 1870 , after applying for fifteen years, that $I$, assisted by the same engineers, was permitted to arrange the aquarium now existing there, and which possesses the same seawater, never since renewed, nor has it been changed in marine aquaria, which I set up in Paris in 1860 and Hamburg in $\mathbf{1} 862$.

It is a pity that no one in Britain seems inclined to work our British aquatic animals, marine and fresh-water, as Dohrn exhibits and studies those of the Mediterranean and the rivers adjoining it ; and British creatures of the same range of organisation, viz., sponges to fishes, are quite as interesting and almost as brilliant as those of the South of Europe.

We can, with modern appliances, possess these forms of life in perfect health, even inland, especially as recent improvements in manufacturing artificial sea-water causes it to be quite as good and as lasting as water from the sea. In Berlin and Hanover it has been so used for years on a large scale. In a small way it was employed long ago by Warington, Gosse, and by myself, and now, in the February, 1880 , number of the Midland Natu. ralist, can be seen how wonderfully successful Mr. H. W. Jones has been with it in a great aquarium, in conjunction with me, in a place where water brought from the ocean would have cost more than six times as much.

W. A, LIOYD

4, Zingari Terrace, Gipsy Road, Lower Norwood, April 6

\section{Ice Crystals and Filaments}

SoMETHING very like the "comb-like masses of ice " appears upon the surfaces of plaster-models such as dentists make, after they have been coated with a preparation called Liquid Silex; except that it is finer and woolly. It seems to be caused by the contraction of the models forcing out very fine jets of water or watery vapour, which dissolves the coating and spins it out until dried and fixed in the shape we find it. The varnish is readily soluble in water.

Port Jervis, New York, U.S., March 20

S. T. BARRETT

\section{Ozone}

WILL you please allow me to make a suggestion concerning an additional element of observation at climatological stations? I refer to the observing of ozone. As the salubrity of a district to a great extent depends on this powerful factor, would it not be well to include ozone in climatological observations, especially in the case of hill and valley stations? The tests wonld, I think, at least enable some conclusions to be drawn as to the purity and salubrity of the atmosphere at the different health resorts, and in my opinion present means, even though imperfect, should on no account be neglecte $a$ until better are found. They might be exposed on a hook in Stevenson's thermometer screen, as recommended by Mr. Buchan; but I find that this plan is only of service during dry weather, and I think Clarke's ozone cage is preferable.

Farley, near Oakamoor, Cheadle

CLEMENT L. WRAGGE

\section{Meteors}

$O_{N}$ the night of April 4, between 10.5 and 10.25 p.m., I observed the following four meteors, viz. :-

$x$. Crossing the "Chair of Capiopoia," at an angle of $45^{\circ}$ with the horizon, from the direction of Ursa Minor. Course about $20^{\circ}$, time about 2 seconds, leaving a train.

2. From $10^{\circ}$ east of Capella to $10^{\circ}$ below Regulus, nearly parallel with the horizon, passing below Castor and Pollux and above Procyon. Course about $80^{\circ}$, time about 5 seconds, leaving. a train, and breaking up into several fragments before its final disappearance, the fragments travelling one behind the other in the same direction. I have never before seen a meteor of this kind with so long a course.

3. From $10^{\circ}$ west of Castor and Pollux, to $5^{\circ}$ west of them, leaving a train. The trains of these three meteors were all of the same bluish white colour. Their radiant points would probably be somewhere between Ursa Minor and Cassiopaia.

4. In exactly the contrary direction, just alove Castor and Pollux. Course about $5^{\circ}$, leaving no train, or a very faint one.

\section{Birstal Hill, Leicester}

F. T. MotT

THE meteor described by your correspondent "B. W. S." was also observed by me at Bristol traversing a long path of $59^{\circ}$ from $247^{\circ}+42^{\circ}$ to $200^{\circ} \pm 0^{\circ}$. It was brighter than Jupiter, and travelled very slowly, the estimated duration being 7 or 8 seconds. The nucleus cast off a tail of sparks as it went along, and varied very perceptibly in brightness. At mid-course it seemed near extinction, but suddenly revived to its previous brilliancy, which was then sustained until near the end point.

A comparison of the meteor's track, as recorded at the two places, shows it to have been directed from a radiant near $\psi$ Cygni (at $297^{\circ}+52^{\circ}$ ), and it is important to know whether any observations were made at additional places. The long duration of the meteor and its very conspicuous apparition in the evening sky must have brought it under the notice of a host of observers. Ashley Down, Bristol, April 5 